\title{
Primary conifer succession on a 1915 mudflow in Lassen Volcanic National Park, California
}

\author{
Glenn Clinton Kroh ${ }^{1}$, Rebecca Laura Upjohn ${ }^{1,2}$ and John Edgar Pinder III, ${ }^{1,3 *}$ \\ ${ }^{1}$ Department of Biology, Winton Scott, Room 401, Texas Christian University, Fort Worth, TX 76129, United States of \\ America. \\ ${ }^{2}$ Department of Ecosystem Science and Management, University of Wyoming, Laramie, Wyoming, WY 82070, United \\ States of America. \\ ${ }^{3}$ Department of Environmental and Radiological Health Sciences, Colorado State University, 305 W. Magnolia PMB 231; \\ Fort Collins, CO 80521, United States of America. \\ Received 29 October, 2014; Accepted 5 December, 2014

\begin{abstract}
Repeated observations of forest development using permanent plots can map pathways and rates of primary succession at the individual plant, the plot and the community level. This study re-measures the trees in $34100 \mathrm{~m}^{2}$ plots that were first sampled in 1987 to document recent and to predict continued forest development for a mixed-conifer forest established on a volcanic mudflow formed at a 2000-m elevation in Lassen Volcanic National Park (LVNP) in 1915. In 1987 and 2008, trees $\geq 0.11-\mathrm{m}$ tall were identified to species level, and measured for height $(\mathrm{m})$ and basal area $\left(\mathrm{m}^{2}\right)$. The most abundant species in both 1987 and 2008 were Pinus contorta, Abies magnifica and Pinus monticola, and there was no statistically significant difference in species composition despite a $20 \%$ increase in tree densities. From 1987 to 2008, the mean ( \pm SE) proportional rates of increase for the number of trees per plot, the mean heights of trees and the total basal area per plot were, respectively, $0.009 \pm 0.002 \mathrm{y}^{-1}, 0.023 \pm 0.002 \mathrm{y}^{-1}$, and $0.055 \pm 0.004 \mathrm{y}^{-1}$. Despite these increases, canopy closure has not occurred for most of the forest. This lack of closure, in conjunction with the continuing similarity of relative species abundances, suggests that abiotic factors such as snow damage and drought and not biotic interactions such as competition may still be the major limitation to tree growth and forest development. Projecting the current rates of basal area growth for the next 10 to 20 years suggests rapid forest development that includes canopy closure. In expectation of these rapid changes, data on tree positions within plots were collected to allow the fates of individual trees to be monitored and determined.
\end{abstract}

Key words: Pinus contorta, conifers, primary succession, volcanism, mudflow.

\section{INTRODUCTION}

Active volcanic mountain ranges from much of the terrain in the American Pacific Northwest (Kiver, 1982; Harris, 1988), and where eruptions of those volcanoes involving pyroclastic blasts, lava flows, lahars, mudflows to landslides that can destroy existing, sometimes very old forests and create newly-formed mineral surfaces

${ }^{*}$ Corresponding author. E-mail: jepinder@uga.edu. Tel: (970) 581-7762.

Author(s) agree that this article remain permanently open access under the terms of the Creative Commons Attribution License 4.0 International License 
(Dale et al., 2005b). Re-establishment of forests on these newly-formed surfaces through primary succession involves the establishment and growth of tree seedlings on inhospitable, bare surfaces of lava, cobble, gravel, muds, tephra or other rocky debris (Frenzen and Franklin, 1985; Drake, 1993; Larsen and Bliss, 1998; Dale et al., 2005a; Munoz-Jimenez et al., 2005). Although other forms of vegetation, including nitrogen-fixing herbaceous plants (Morris and Wood, 1989; Halpern et al., 1990; Walker et al., 2003; del Moral and Rozzell, 2005; Titus and Bishop, 2014), may either inhibit or facilitate the establishment of tree seedlings as they do for other herbaceous species, but the initial survival and growth of seedling and sapling trees may often be dependent upon their ability to survive harsh abiotic factors such as the physical extremes of temperature, light intensity, drought, snow pack and low nutrient availability (Turner, 1985; Alejandre-Melena et al., 2007; Deligne et al., 2013). Seedling and sapling trees may have to persist and grow slowly for decades before the they become large enough for their crowns to merge into a closed-canopy forest (Heath, 1967b).

As trees increase in size and the canopy of the forest closes, the factors limiting the survival and growth of trees may shift from these abiotic extremes of physical factors to biotic factors including competition for light and nutrients. This shift in the primary limiting factors may cause changes in the relative success of different individuals and different species (Peet and Christiansen, 1980; Walker and Chapin, 1987; Walker and del Moral, 2003). For example, competition for light among shade intolerant species such as pines and other conifers results in self-thinning (Dewar, 1993; Zeide 1995, 2001; Walker and del Moral, 2003) where there are greater mortality rates for shorter individuals whose crowns are in the forest's shaded lower subcanopy than for taller individuals with crowns in the forest's upper canopy. For intraspecific competition for light in some conifers such as Pinus taeda (VanderSchaaf, 2010), Pseudotsuga menziensii (Weiskittel et al., 2008) and Pinus contorta (Dean and Long, 1992), the progressive pattern of declining densities and increasing sizes of surviving individuals may follow predictable patterns where stands of initially different densities converge to similar densities and similar individual tree sizes.

The abilities to predict 1) the path of the plant succession and 2) the rate at which succession will produce forests that are either similar to or different from those that were destroyed is important in understanding: 1) the structure, composition and ecology of the Pacific Northwest forests (Acker et al., 1987) and 2) the processes of primary succession in general. Because of the long time frames required for forest succession, this process of forest development is usually inferred from historic reconstruction based on surviving trees (Johnson et al., 1994; Fastie, 1995) or from chrono sequences where forest development is compared among similar sites of varying ages (McCune and Allen, 1985; Drake and Mueller-Dumbois 1993; Clarkson, 1997; Walker et al., 2010).

It may be that studies involving repeated observations and measurements through time on permanent plots could be preferable to historic reconstructions and comparisons of sites of different ages (Bakker et al., 1996), and as similar studies of permanent plots have proven effective in understanding the processes involved in the establishment of herbaceous communities on volcanic terrains (Dale and Adams, 2003; Halpern et al., 1990; del Moral, 2007; del Moral et al., 2010, 2012; del Moral and Magnusson, 2014). Continued observations on permanent plots may also enable investigators to generate and test hypotheses on potential mechanisms driving succession (Bakker et al., 1996; Herben, 1996; Csecserits et al., 2007). Permanent plots have also been recommended as a possibly preferable method for monitoring changes through time in vegetation (Walker and del Moral, 2003; Chytry et al., 2014). Results from studies of forest development in repeatedly sampled permanent plots could be of fundamental importance in complementing and assessing the accuracies of historic reconstructions and comparisons of different-aged sites, but such long-term, permanent plot studies for tree species (Heath, 1971; Woods, 2000; Harcombe et al., 2002; Kangur et al., 2005; Weber et al., 2006) are less common than those for shorter-lived herbaceous and shrub communities.

This study reports on repeated observations of forest development using permanent plots that were originally established and studied in 1987 (Kroh et al., 2000) on a 1915 volcanic mudflow in Lassen Volcanic National Park (hereafter, LVNP) in northern California, USA $\left(40^{\circ} 30^{\prime} \mathrm{N}\right.$, $\left.121^{\circ} 26^{\prime} \mathrm{W}\right)$. These permanent plot measurements are complemented and supported by a combination of historical photographs, aerial photographs, unpublished National Park Service reports (Swartzlow, 1946; Bailey, 1961), theses and dissertations (Bailey, 1963; Heath, 1967a; Fessenden, 1984; Eppler, 1984; Upjohn, 2009), and published research (Heath, 1967b; Eppler, 1987; Parker, 1993) that have documented tree establishment and growth on the surface of the mudflow since 1940.

The purposes of the present study were: 1) to resample the 1987 permanent plots, 2) determine the rates of change in forest composition and structure, and 3) use these rates of change to predict the development of forest structure and composition that may be expected to occur in the next 10 or more years. This resampling was prompted by visits to the site in 2003 and 2008 which 1) suggested that the forest may be approaching canopy closure and the potential period of transition from primarily abiotic to primarily biotic limiting factors and 2) emphasized the need for documentation of forest structure and composition before the onset of canopy closure and its associated changes in forest structure had begun. 


\section{METHODOLOGY}

\section{Site description and history}

The mudflow site is part of a larger area of volcanic disturbance termed the Devastated Area that was formed within LVNP by eruptions in May 1915. This area is located on the northeast slope of Lassen Peak at elevations > 1900-m amsl where the climate type is dry upland with winter snows and frequent summer droughts (Griffin, 1967). The predominant forest type at these elevations and aspects within LVNP is pine, especially Pinus contorta (Douglas; species nomenclature follows Hickman, 1993). Although $P$. contorta and other pines are the predominant forest type, there are local variations due to slopes and aspects (Parker, 1991).

Two separate days of eruptions were involved in the formation of the Devastated Area. During the first eruption on 19 May 1915, magma surfaced at the summit, melted the surrounding snowpack, and caused a fast-moving, water and mud based landslide, termed a lahar (Eppler, 1984, 1987), which flowed northerly along the floodplains of Lost Creek and Hat Creek destroying existing vegetation and leaving $\leq 1.5-\mathrm{m}$ deep sediment deposits (Eppler, 1984). Additional eruptions on 22 May 1915 involved three main components including, in the sequence which they occurred: 1) a lateral blast of hot gasses that uprooted, broke-off or burned trees, seedlings and other vegetation (Swartslow, 1946) in a northeasterly direction for $>5 \mathrm{~km}$; 2) a fast-moving lahar that deposited additional sediments on the previous deposited 19 May Lost Creek lahars; and 3) an apparently more viscous and slower-moving mudflow involving $10^{6} \mathrm{~m}^{3}$ of material (Eppler, 1984, 1987) that came to rest on sloping terrain south of Lost Creek ( $121^{\circ} 28^{\prime} 10^{\prime \prime} \mathrm{W}, 40^{\circ} 30^{\prime} 45^{\prime \prime}$ $\mathrm{N})$. Whereas, the previous lahars had followed the existing streambed of Lost Creek, most of this mudflow was deposited on top of upland terrains, whose nature is obscured by the depths of the deposits, or the previous lahar deposits. The shallowest deposits occurred on the mudflow's easternmost section of preexisting soils where forest cover had been blown down by the earlier blast (Figure 1) (Kroh et al., 2000).

This mudflow is characterized by a discrete, lobate terminal margin with leading edges marked by steep-sided deposits $\geq 0.3-\mathrm{m}$ thick (Eppler, 1984, 1987) and being composed of fractured, banded-dacite rocks containing alternating layers of white dacite and black andesite (MacDonald and Katsura, 1965). Although some portions of the site appear to have been deposited as a debris flow rather than a mudflow (Eppler, 1987), the use of the term "mudflow" follows Eppler's (1984) analysis. This nomenclature cannot be resolved with the lahar (including mudflow), debris flow and avalanche terms of del Moral and Grishin (1999) as the initial water content of the flow is unknown.

The mudflow surface is variable with 1) some areas of steep slopes, 2) the presence of up to 1-m diameter dacite blocks at higher elevations, 3) approximately $1-\mathrm{m}$ deep craters formed by outgassing from buried hot boulders (Eppler, 1984), and 4) relatively flat terrains on the lower elevations. The nearby Lost Creek lahar deposits from the 19 and 22 May eruptions and their developing vegetation have been subsequently disturbed by stream erosion and overwash (Eppler, 1984; Heath, 1967b), but the mudflow surface has remained mostly free of these disturbances. In contrast to studies at other sites described as debris flows (Yoshida et al., 1997), mudflows (Frenzen et al., 2005) or lahars (Larsen and Bliss, 1998), this mudflow did not include patches of trees that could provide a ready source of propagules to initiate forest recovery.

\section{Previous studies of forest development on the mudflow}

Early studies of plant community development on the mudflow used various plot designs and were mostly conducted on the lower elevations of the mudflow on relatively flat terrains. Swartslow (1946) sampling in a $30.3 \times 30.3 \mathrm{~m}$ plot in 1936, 1940 and 1946 reported approximately 30,000 forbaceous individuals per ha (3 individuals per $\mathrm{m}^{2}$ ) with the species Ericameria bloomer ( A. Gray) J. F. Macbr. and Calyptridium umbellatum ((Torrey) E. Greene each comprising approximately $40 \%$ of the individuals. The lupine species, Lupinus andersonii (S. Watson) and Lupinus grayi (S. Watson), had densities of 839 and 279 individuals per ha, respectively. A single $P$. contorta was observed in the plot. Bailey (1961), sampling during 1960 in a different $30.3 \times 30.3 \mathrm{~m}$ plot, mapped and measured the heights of 181 conifers $(1,970$ trees ha $\left.{ }^{1}\right)$. Relative conifer abundances on this plot decreased in the order Abies spp., P. contorta, Tsuja mertensiana (Bong.) Carriere, Pinus monticola (Douglas) and Pinus jeffreyi (Grev. \& Balf.). Tree heights ranged from $0.15 \mathrm{~m}$ to one 9.1-m tall $P$. contorta. Bailey (1961) noted that conifers were approximately four times more numerous than lupines and commented that "shifting wind currents ... could apparently have brought seeds in from all directions...". Bailey (1963) also reported tree densities and maximum tree heights in 1962 for twenty, contiguous $1.83 \times 18.3 \mathrm{~m}$ sections of a belt transect (CTT4) crossing the lower elevations where tree densities were 1,433 trees per ha with $69 \%$ being $P$. contorta $<4-\mathrm{m}$ tall and $18 \%$ Abies spp. < 2-m tall. Heath (1967a) mapped and measured the heights of 251 conifers in a $3 \mathrm{~m}$ by $152 \mathrm{~m}$ belt transect in 1963 where the relative abundances of the species were $P$. contorta, Abies concolor ((Gordon \& Glend.) Lindley), P. monticola, Abies magnifica (Andr. Murray), T. mertensiana and $P$. jeffreyi. Tree heights ranged up to 4.27-m tall for $P$. contorta and $P$. monticola. Although the results of Swartzlow (1946), Bailey $(1961,1963)$ and Heath (1967a) are based on sampling of single, relatively small square or belt-shaped areas, their results are consistent with the general appearance of the mudflow site in panchromatic aerial photographs from 1941 and 1966, respectively.

To sample the tree, shrub and forb vegetation on the mudflow in1982, Fessenden (1984) used 5-m radius, circular plots spaced 31-m apart along a series of south to north transects arranged at intervals of $61 \mathrm{~m}$. Fessenden (1984) divided the mudflow into a Dense Forest Margin (hereafter, DFM) and a Sparse Central Forest (hereafter SCF) areas. The SCF corresponds to the area where the mudflow was deposited over previous lahar sediments (Kroh et al., 2000), whereas the DFM corresponds to the area of mudflow deposits over preexisting soils. In the 34 SCF plots, tree densities were 1,946 individuals per ha with $P$. contorta, $A$. magnifica and $P$. monticola accounting for 61,19 and $13 \%$, respectively, of the trees. Tree heights and stem diameters were not reported.

\section{Initial permanent plot sampling in 1987}

In 1987, Kroh et al. (2000) established four parallel transects spaced at intervals of $200 \mathrm{~m}$ that 1) crossed the full width of the mudflow and 2) were oriented at right angles across the direction of the flow's path. These transects ranged from the uppermost elevations $(\mathrm{H} 1)$ down to the lowest elevation $(\mathrm{H} 4)$ which had been studied by Swartzlow (1946), Bailey (1961, 1963) and Heath (1967a, 1967b), and the area sampled on transects H2, H3 and H4 corresponded to Fessenden's SCF (Kroh et al., 2000). Circular 100$\mathrm{m}^{2}$ (radius $=5.64 \mathrm{~m}$ ) sample plots were established at $20-\mathrm{m}$ intervals along each transect for a total of 70 plots. Global Positioning Systems using post-processing, differential corrections (El-Rabbany, 2002; Dodd, 2011) were used to determine plot locations within the positional accuracies necessary for sequential sampling of permanent plots (Ross et al., 2010; Dodd, 2011). Plot elevations were measured using single-based barometric surveying (Davis et al., 1981). The mean elevations for the plots on transects $\mathrm{H} 1$ through $\mathrm{H} 4$ were 2033, 2005, 1989 and $1977 \mathrm{~m}$ amsl, respectively. More complete descriptions of transects and plots and 


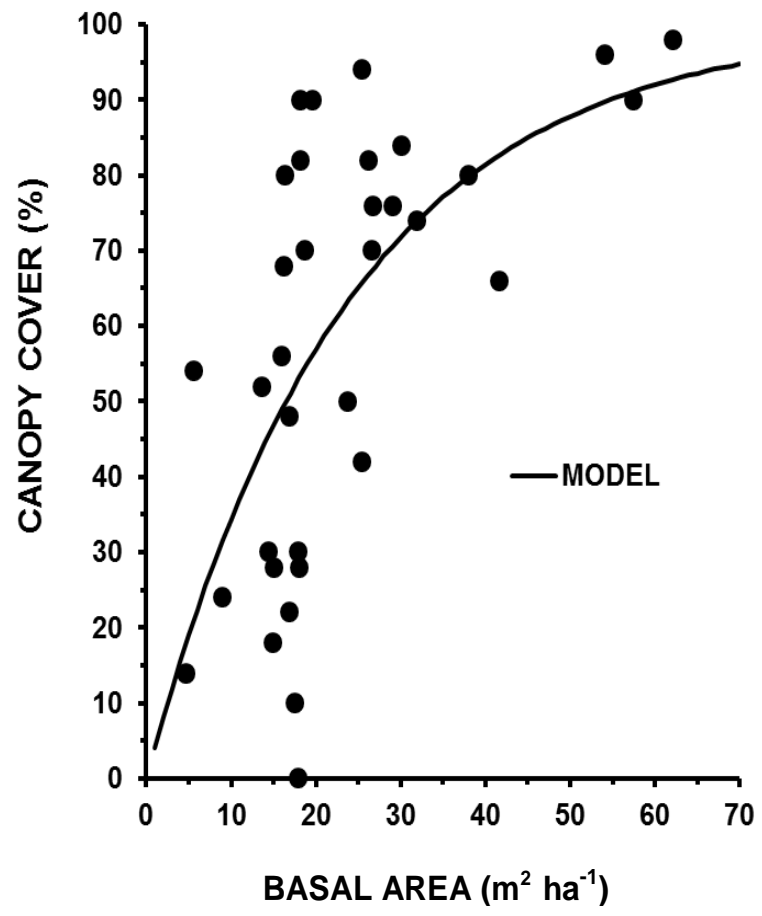

Figure 1. The relationship between plot basal area and canopy cover for 34 plots on the mudflow.

maps of the site are available in Kroh et al. (2000).

Each plot was visited in 1987 with all living trees being identified to species level and measured for height and, for trees $\geq 1.37 \mathrm{~m}$ tall, diameter-at-breast height (hereafter, dbh). Tree heights $\leq 2 \mathrm{~m}$ were measured with stadia rods. Heights $>2 \mathrm{~m}$ were measured trigonometrically based on line-of-sight angles to the base and the top of the tree from a known distance. Calipers were used to measure $\mathrm{dbh}$. Trees with $\mathrm{dbh} \geq 80 \mathrm{~mm}$ had a $5.15-\mathrm{mm}$ diameter increment core extracted as near to the ground surface as possible for the determination of age by ring counts (Kroh et al., 2000 for methods of determining ring counts). Trees too small for increment coring were aged by counting whorls that demark annual increments of height growth. Few dead trees were seen, and these were not measured. In all procedures, care was taken to minimize damage to the trees and disturbances to the mudflow surface. A number of trees $>3-m$ tall were labelled for subsequent identification using numbered, metal tags hung loosely on the tree with rubber-shielded wire.

The 1987 sampling indicated a short-stature (median tree heights $<2 \mathrm{~m})$, dense $\left(3,507\right.$ trees $\left.^{-1}\right)$ forest of conifers who were mostly $\leq 50$ year-old (Kroh et al., 2000). The species composition was, as listed in order of decreasing abundance, $P$. contorta, $A$. magnifica, $P$. monticola, $A$. concolor, $P$. jeffreyi and $T$. mertensiana (Kroh et al., 2000). This conifer assemblage contains a mix of shade intolerant and shade tolerant species with intolerance to shade increasing in the order T. mertensiana, A. concolor, A. magnifica, $P$. monticola and P. contorta (Minore, 1979).

These species differed in their abundances, but their age distributions indicated similar dates of first invasions with each species being present by the mid-1940s (Kroh et al., 2000). The predominance of $\leq 50$-year-old trees was consistent with photographic evidence showing the development of large, presumably seed-producing, trees beginning in 1940 on the previously denuded, blast-effected, upland areas surrounding the mudflow (Kroh et al., 2000). The age distributions measured by
Kroh et al. (2000) were also consistent with the pattern of tree invasion apparent in historical photographs (Stillman and Turnage, 1962) of known dates (Kroh et al., 2000).

For $P$. contorta, there were gradients of increasing densities and increasing basal areas from the upper transects to the lower transects, and these gradients contributed to similar overall gradients for the total forest. There were also other less pronounced gradients in species abundances with elevation that included an increase in densities of $A$. concolor at lower elevations.

\section{Permanent plot sampling in 2008}

Forest structure in 2008 was determined for every second plot along these transects because the $20-\mathrm{m}$ interval between plot centers may not prove sufficient to ensure future independence between large trees in neighboring plots. Thus, data are reported for only 34 of the 70 plots. Heights for every tree $\geq 0.11-m$ tall and dbh's for each tree $\geq 1.37-\mathrm{m}$ tall were measured using methods consistent with those in 1987. The trees were also inspected for damage such as broken, bent or dead upper main stems, and the presence of female cones. In addition, the position of all trees that were $\geq 0.11-\mathrm{m}$ tall were determined by measuring the compass bearing to and the distance from the center of the plot. A few dead trees were observed in the forest, but none of these occurred in the sampled plots. Canopy cover, expressed as the percent of sky obscured by the forest canopy, was determined as the mean of two concave spherical densitometer (Lemmon, 1956) measurements taken from the plot center while alternatively facing east and west.

\section{Statistical procedures}

Statistical procedures were performed using version 9.3 of the Statistical Analysis System (hereafter SAS; Der G, 2001) using a probability $(P)$ level of 0.05 for statistical significance. Paired observations of data between plots from 1987 and 2008 were analyzed using t-tests of paired observations. Analyses of nonpaired observations were conducted using analysis of variance (hereafter ANOVA; Milliken and Johnson, 1984). Where significant differences among means were indicated by ANOVA F-tests, the differences between means required for statistical significance was computed using the T-method of multiple comparisons for unequal sample sizes (Spjotvoll and Stoline, 1973; Milliken and Johnson, 1984). Correlations were evaluated using Spearman rank correlations which are less sensitive to departures from normality than Pearson product-moment correlations (Conover, 1971). Tests to determine statistically significant differences among proportional abundances were performed using likelihood-ratio Chi-square procedures (Conover, 1971). Nonlinear regressions were performed using PROC NLIN of SAS (SAS Institute Inc., 2003).

\section{RESULTS}

To compare species abundances and tree sizes between the 1987 and 2008 plot data, all the $<0.11$-m tall trees in the 1987 data were deleted to obtain corresponding ranges in height data from the two sample periods. Only 58 trees $<0.11-\mathrm{m}$ tall, including $39 P$. contorta, were removed from the 1987 data. There was an increase in the total number of trees $\geq 0.11-\mathrm{m}$ tall from 1,167 in 1987 to 1,398 in 2008 (Table 1), and there were also increases for each of the species (Table 1). There was no statistically significant difference in the relative abundances among the species between years (likelihood ratio $X^{2}=$ $1.55 ; \mathrm{P}>0.05)$. 
Table 1. The number of trees of each of the six conifer species observed in the 34 100-m2 plots in 1987 and 2008.

\begin{tabular}{lcc}
\hline \multirow{2}{*}{ Species } & \multicolumn{2}{c}{ Number Observed } \\
\cline { 2 - 3 } & $\mathbf{1 9 8 7}$ & $\mathbf{2 0 0 8}$ \\
\hline Abies concolor & 25 & 40 \\
Abies magnifica & 172 & 206 \\
Pinus contorta & 797 & 939 \\
Pinus jeffreyi & 24 & 31 \\
Pinus monticola & 130 & 158 \\
Tsuga mertensiana & 19 & 24 \\
\hline
\end{tabular}

\section{Comparisons of tree densities, heights and basal areas between 1987 and 2008}

The mean tree density, mean tree height and mean sum of tree basal areas in the sample plots for the four transects are summarized in Table 2 for 1987 and 2008. The differences among transects for the 1987 data in Table 2 were statistically significant as indicated by differences between means being greater than the Tinterval, and there were gradients of increasing density and increasing basal area from $\mathrm{H} 1$ to $\mathrm{H} 4$. For the 2008 samples, there were no statistically significant differences among transects for any of these variables, and the ratios of largest to smallest means were all $<2$, whereas similar ranges among transect means for these 34 plots in the 1987 data were all $>2$ with the ratio for basal area being $>4$.

Tree densities in 2008 were greater than those in 1987 for all but 5 plots. The mean $( \pm$ SE) tree densities per plot for 1987 and 2008 were, respectively, $34.3 \pm 2.9$ trees $/ 100 \mathrm{~m}^{2}\left(3,430 \pm 290\right.$ trees $\left.\mathrm{ha}^{-1}\right)$ and $41.2 \pm 3.2$ trees $/ 100 \mathrm{~m}^{2}\left(4,120 \pm 320\right.$ trees $\left.\mathrm{ha}^{-1}\right)$ and mean $( \pm \mathrm{SE})$ densities per plot increased significantly (t-test of paired observations $\mathrm{t}=4.29 ; \mathrm{df}=33 ; \mathrm{P}<0.01$ ) by $6.8 \pm 1.6$ trees $\left(680 \pm 160\right.$ trees $\left.^{-1}\right)$.

The changes in densities may reflect 1 ) the mortality of trees that were $\geq 0.11-\mathrm{m}$ tall in 1987,2 ) the growth of 1987 trees that were $<0.11-\mathrm{m}$ tall to $\geq 0.11-\mathrm{m}$ tall in 2008 or 3 ) the germination and growth of trees that were not present in 1987. The relative importance of these processes cannot be completely evaluated from the currently available data because quantifying these alternative processes requires being able to identify the fates of individual trees. However, because 1) the number of trees increased by $231(1398-1167)$ while 2$)$ only 58 trees $<0.11-\mathrm{m}$ tall were removed from the 1987 data, most $(\leq 231-58)$ of the increase in densities must represent new individuals who germinated and grew to $\geq$ $0.11-\mathrm{m}$ tall during the intervening 21 years.

Although all conifer species had increased numbers of individuals, female cones were only observed on a single $P$. monticola and $22 \%$ of the $P$. contorta. The female cones on the $P$. contorta included those produced in previous years, but it is not clear what proportion, if any, of these cones had released seeds.

The mean $( \pm S E)$ proportional rate of increase in density among plots, estimated as the mean of the logarithms of density in 2008 minus that in 1987 divided by 21 years, for each of the plots, was $0.009 \pm 0.002 \mathrm{y}^{-1}$, and there were no statistically significant differences in mean proportional rates of increasing density among transects (Table 3; ANOVA F $=0.80 ; \mathrm{df}=3,30 ; \mathrm{P}>0.05$ ). The proportional rates of increase for the more abundant species were also similar to this mean value.

The mean height of the trees per plot in 2008 was greater than in 1987 for all of the plots. Mean ( \pm SE) heights per plot in 2008 and 1987 were, respectively $3.23 \pm 0.35 \mathrm{~m}$ and $1.98 \pm 0.23 \mathrm{~m}$, and the mean ( $\pm \mathrm{SE}$ ) height increase per plot of $1.25 \pm 0.03 \mathrm{~m}$ was statistically significant as indicated by 1$)$ a t-test of paired observations $(t=7.87$, df $=33 ; \mathrm{P}<0.01$ ) and 2) the increase in all of the 34 plots. The mean $( \pm$ SE) proportional rate of height increases $(y$ ${ }^{1}$ ), estimated as the mean of the logarithm of mean height in 2008 minus that in 1987 divided by 21 years for each of the plots, was $0.023( \pm 0.002) \mathrm{y}^{-1}$, and there were no statistically significant differences in mean proportional height growth rates among the four transects (Table 3; ANOVA F $=0.53 ; \mathrm{df}=3,30 ; \mathrm{P}>0.05$ ).

There were increases in mean tree heights between 1987 and 2008 for all species except T. mertensiana. The median, mean and maximum tree heights for each species in each year of sampling are summarized in Table 4, and the 2008 mean heights are generally $>1.3$ times those in 1987. The largest increase in mean heights of $1.07 \mathrm{~m}$ occurred for $P$. contorta, but this increase was similar to those for the other two most abundant species $P$. monticola $(0.90 \mathrm{~m})$ and $A$. magnifica $(0.87 \mathrm{~m})$. A more involved interpretation of these changes in mean heights is complicated by the addition of trees that were established after 1987, but the data do suggest similar increases in mean heights among the most abundant species over the 21-year period.

This similarity in height growth among species was also observed for 96 tagged trees located within the 34 plots. Mean proportional rates of height growth (Table 5) ranged from $0.019 \mathrm{y}^{-1}$ for $P$. jeffreyi to $0.031 \mathrm{y}^{-1}$ for a small number of $A$. concolor, and there was no significant difference in rates among species in either height growth $(\mathrm{F}=1.09 ; \mathrm{df}=4,91 ; \mathrm{P}>0.05)$ or basal area $(\mathrm{F}=2.41 ; \mathrm{df}$ $=4,91 ; \mathrm{P}>0.05)$. The mean $( \pm \mathrm{SE})$ proportional height growth rate for all 96 trees was $0.022( \pm 0.001) \mathrm{y}^{-1}$ which is similar to the mean proportional growth rates per plot (Table 3).

Mean tree heights increased in all plots, but decreases in mean heights could have occurred due to 1) additions of numerous newer and smaller trees or 2) damage to existing trees. There was a statistically significant Spearman Rank Correlation of $-0.38(n=34 ; P<0.05)$ between the increases in tree numbers and the increases in mean tree heights among plots, and a plot where the 
Table 2. Means \pm standard errors of tree density (number per $\mathrm{m}^{2}$ ), mean tree height $(\mathrm{m})$, and total basal area per plot $\left(\mathrm{m}^{2}\right.$ ha $\left.{ }^{-1}\right)$ for transects $\mathrm{H} 1$ though $\mathrm{H} 4$.

\begin{tabular}{|c|c|c|c|c|c|c|c|c|c|}
\hline \multirow{2}{*}{ Transect } & Number of plots & Tree densities & Tree heights & Plot basal areas & \multirow{2}{*}{ Transect } & Number of plots & Tree densities & Tree heights & Plot basal areas \\
\hline & & Mean \pm SE & Mean \pm SE & Mean \pm SE & & & Mean \pm SE & Mean \pm SE & Mean \pm SE \\
\hline \multicolumn{6}{|c|}{1987} & \multicolumn{4}{|c|}{2008} \\
\hline $\mathrm{H} 1$ & 7 & $22.7 \pm 1.9$ & $1.29 \pm 0.18$ & $3.14 \pm 0.63$ & $\mathrm{H} 1$ & 7 & $30.0 \pm 3.1$ & $2.29 \pm 0.41$ & $14.6 \pm 1.7$ \\
\hline $\mathrm{H} 2$ & 10 & $319 \pm 5.0$ & $1.86 \pm 0.26$ & $6.73 \pm 0.92$ & $\mathrm{H} 2$ & 10 & $39.2 \pm 5.9$ & $3.31 \pm 0.59$ & $21.6 \pm 2.2$ \\
\hline H3 & 8 & $31.6 \pm 5.6$ & $2.96 \pm 0.73$ & $11.6 \pm 2.6$ & $\mathrm{H} 3$ & 8 & $38.8 \pm 5.5$ & $4.37 \pm 0.98$ & $30.8 \pm 5.1$ \\
\hline $\mathrm{H} 4$ & 9 & $48.4_{ \pm} 5.7$ & $1.87 \pm 0.40$ & $12.9 \pm 3.8$ & $\mathrm{H} 4$ & 9 & $54.1_{ \pm} 6.9$ & $2.89 \pm 0.66$ & $26.5 \pm 6.3$ \\
\hline T-interval & & 21.5 & 1.62 & 22.6 & T-interval & & 29.9 & 3.58 & 22.6 \\
\hline
\end{tabular}

Table 3. Mean \pm SE of proportional rates of increase $\left(y^{-1}\right)$ in tree densities, mean tree heights per plot, and total basal areas per plot for transects $\mathrm{H} 1$ though $\mathrm{H} 4$.

\begin{tabular}{lcccc}
\hline \multirow{2}{*}{ Transect } & Number of plots & Tree Densities & Tree Heights & Plot Basal Areas \\
\cline { 2 - 5 } & & Mean \pm SE & Mean \pm SE & Mean \pm SE \\
\hline H1 & 7 & $0.012 \pm 0.005$ & $0.026 \pm 0.003$ & $0.079 \pm 0.008$ \\
H2 & 10 & $0.009 \pm 0.005$ & $0.025 \pm 0.004$ & $0.057 \pm 0.005$ \\
H3 & 8 & $0.011 \pm 0.003$ & $0.022 \pm 0.003$ & $0.051 \pm 0.007$ \\
H4 & 9 & $0.005 \pm 0.002$ & $0.021 \pm 0.002$ & $0.039 \pm 0.006$ \\
T-interval & & 0.042 & 0.009 & 0.017 \\
\hline
\end{tabular}

density increased from 29 to 72 had an increase in mean height of only $0.14 \mathrm{~m}$. Also, approximately $32 \%$ of all trees showed some indication of damage that may have affected height growth. Damage, which was primarily in the form of bent or broken upper stems, suggested physical damage or stress from wind, deep snow accumulation, or down slope movement of the upper portions of the winter snow pack. Fessenden (1984) noted wind and snow damage and reported two episodes of avalanches on the mudflow in 1972 and 1982. Damage varied significantly among species (likelihood ratio $X^{2}=246.9$; $\mathrm{df}=$ $12 ; \mathrm{P}<0.01)$ with the most abundant species $P$. contorta, A. magnifica and $P$. monticola having damage percentages of 36, 22 and $32 \%$, respectively. Although the additions of new small trees and the damage to existing trees were not sufficient to result in reductions in the mean heights for plots, they probably affected mean height growth rates.

The total basal area per plot, computed as the sum of the basal areas for all the sufficiently tal trees, was greater in 2008 than in 1987 for all the plots (Table 4). The mean ( \pm SE) total basal area per plot in 2008 and 1987 were, respectively, 23.6 $\pm 2.3 \mathrm{~m}^{2} \mathrm{ha}^{-1}$ and $8.8 \pm 1.3 \mathrm{~m}^{2} \mathrm{ha}^{-1}$, and the mean $\left( \pm\right.$ SE) increase in basal area of $14.9 \pm 1.2 \mathrm{~m}^{2} \mathrm{ha}^{-1}$ was statistically significant as indicated by 1) a ttest of paired observations $(t=12.3$; $d f=33$; $P<$
0.01 ) and 2) an increase in all of the 34 plots. The increase in basal areas represents 1) the continual growth of trees with measurable $\mathrm{dbh}$ in 1987 and 2) the development of measurable basal area for trees that were $<1.37-\mathrm{m}$ tall in 1987 but were $>1.37-\mathrm{m}$ tall in 2008 . The number of trees with measurable basal areas increased from 315 in 1987 to 733 in 2008 with all species contributing to this increase. The mean ( \pm SE) proportional rate of increase in total basal area for the plots was $0.055 \pm 0.004 \mathrm{y}^{-1}$, and varied significantly among transects (Table 3; ANOVA F = 6.77; df = 3, 30; $\mathrm{P}<0.01$ ).

The mean $( \pm$ SE) proportional rate of increase in basal areas for the 96 tagged trees (Table 5) was 
Table 4. Tree heights $(\mathrm{m})$ for the species in the 34 plots on the mudflow in 1987 and 2008. SD = standard deviation.

\begin{tabular}{lccccc}
\hline Species & Number of trees & Minimum & Median & Mean \pm SD & Maximum \\
\hline \multicolumn{7}{c}{ A. concolor } & \multicolumn{2}{c}{$\mathbf{1 9 8 7}$} & & & \\
A. magnifica & 25 & 0.19 & 0.99 & $1.48 \pm 2.57$ & 6.20 \\
P. contorta & 172 & 0.12 & 1.12 & $1.95 \pm 2.76$ & 14.7 \\
P. jefferyi & 797 & 0.11 & 0.82 & $1.51 \pm 1.98$ & 13.2 \\
P. monticola & 24 & 0.12 & 1.98 & $2.76 \pm 2.51$ & 8.90 \\
T. mertensiana & 130 & 0.11 & 1.80 & $2.83 \pm 2.01$ & 15.1 \\
\hline & 19 & 0.12 & 1.40 & $1.27 \pm 1.54$ & 5.10 \\
\hline A. concolor & \multicolumn{2}{c}{$\mathbf{2 0 0 8}$} & & & \\
A. magnifica & 40 & 0.11 & 0.92 & $1.98 \pm 2.76$ & 10.7 \\
P. contorta & 206 & 0.11 & 1.54 & $2.82 \pm 3.44$ & 19.2 \\
P. jefferyi & 940 & 0.11 & 1.49 & $2.56 \pm 2.92$ & 21.8 \\
P. monticola & 31 & 0.14 & 2.43 & $3.66 \pm 3.67$ & 13.6 \\
T. mertensiana & 158 & 0.11 & 1.52 & $3.73 \pm 4.00$ & 19.0 \\
\hline
\end{tabular}

Table 5. Mean ( \pm SE) proportional height and basal area growth rates from 1987 to 2008 for 96 tagged trees from the 34 plots. Proportional height and basal area growth rates have units of $\mathrm{y}^{-1}$. There were no statistically significant differences among species for either height growth rates (ANOVA $F=1.09$; $d f=4$, 91; $\mathrm{P}>0.05$ ) or basal area growth rates (ANOVA $\mathrm{F}=2.41$; $\mathrm{df}=4,91 ; \mathrm{P}>0.05$ ), and T-intervals are not reported because of the large variation in sample sizes.

\begin{tabular}{lccc}
\hline \multirow{2}{*}{ Species } & No. of Trees & Mean $( \pm$ SE) & Proportional growth rates \\
\cline { 2 - 4 } & & Height & Basal Area \\
\hline A. concolor & 2 & $0.031 \pm 0.006$ & $0.041 \pm 0.009$ \\
A. magnifica & 16 & $0.021 \pm 0.002$ & $0.043 \pm 0.005$ \\
P. contorta & 57 & $0.022 \pm 0.001$ & $0.031 \pm 0.002$ \\
P. jefferyi & 6 & $0.019 \pm 0.004$ & $0.032 \pm 0.006$ \\
P. monticola & 15 & $0.021+0.002$ & $0.029 \pm 0.005$ \\
\hline
\end{tabular}

Table 6. Mean \pm SE of canopy cover measured as percent of the sky obscured by conifer foliage for the four transects

\begin{tabular}{lcc}
\hline Transect & Number of plots & Canopy cover \\
\cline { 3 - 3 } & 7 & Mean \pm SE \\
\hline H1 & 10 & $25.1 \pm 7.8$ \\
H2 & 8 & $55.6 \pm 7.4$ \\
H3 & 9 & $75.5 \pm 7.4$ \\
H4 & & $70.7 \pm 8.4$ \\
T-interval & & 40.3 \\
\hline
\end{tabular}

$0.033( \pm 0.002) \mathrm{y}^{-1}$ with no significant differences in rates among species $(F=2.41 ; \mathrm{df}=4,19 ; \mathrm{P}>0.05)$. The smaller proportional rate of basal area increase for the tagged trees relative to the increases for the plot basal areas (Table 3 ) reflects the increase in the number of trees that contributed to the total basal area in the plots.

\section{Canopy cover}

Canopy cover ranged from 0 to $98 \%$ with a mean ( \pm SE) cover per plot of $58 \pm 5 \%$ and a median of $67 \%$ (Table 6 ). Canopy cover differed significantly among transects (Table 5; ANOVA on arcsin transformations of percentages $F=6.89, d f=3,30 ; P<0.01$ ) with canopy closure increasing from $\mathrm{H} 1$ through $\mathrm{H} 4$. There was also a statistically significant $\left(F=251.4 ; \mathrm{df}=1,33 ; \mathrm{P}<0.001 ; \mathrm{r}^{2}\right.$ $=0.884$ ) asymptotic, nonlinear relationship between basal area per plot and plot canopy cover (Figure 1) of the form,

$Y=100 \%{ }^{*}\left[1-e^{\left(-b^{*} x\right)}\right]$

where $\mathrm{Y}=$ percent canopy closure, $\mathrm{x}=$ basal area in $\mathrm{m}^{2}$ $\mathrm{ha}^{-1}$ and $\mathrm{b}( \pm \mathrm{SE})=0.0421 \pm 0.005$. Most $(29$ of 34$)$ predicted percent covers were within a factor of 2 of the observed percent covers.

There were changes in plot basal area growth rates 
associated with increasing canopy cover. The proportional rate of increase in basal area per plot declined with increasing canopy cover $\left(r_{s}=-0.640 ; n=34 ; P<0.001\right)$. For every $1 \%$ greater canopy cover, there was a 0.00047 $(\mathrm{SE}= \pm 0.0001) \mathrm{y}^{-1}$ decline in the proportional rate of basal area increase. To what extent this decline in rates may be due to 1) shading between larger trees or 2) shading effects of larger trees on smaller trees cannot be evaluated from the present data and would require growth data for individual trees. There was no significant correlation between canopy cover and the proportional rates of increases for densities $\left(r_{s}=0.176 ; n=34 ; P>0.05\right)$ or mean tree heights $\left(r_{s}=-0.145 ; n=34 ; P>0.05\right)$.

Spherical densitometer measures of canopy cover include the attenuation of light passing through the canopy at oblique angles. Thus, they can substantially overestimate cover when compared to devices which measure the proportion of open canopy directly above a number of separate positions (Brunnel and Vales, 1990; Cook et al., 1995). However, Nuttle (1997) has argued that spherical densitometers may provide more appropriate measures of the various influences of the canopy on affecting the light that does not penetrate to near the ground surface. It is the light that does not reach the ground surface that will limit the success of seedlings and smaller trees. Therefore, the use of spherical densitometer readings, which account for the attenuation of light approaching at oblique angles, is more appropriate for this study. Furthermore, the correspondences of the densitometer readings with plot basal areas and proportional rates of increase in plot basal areas suggests that these readings are informative measures of the impact of the larger trees on the attenuation of light resources for the smaller trees.

\section{DISCUSSION}

The changes between the 1987 forest and the 2008 forest involved mostly greater increases in mean heights (by a factor of $1.6=3.23 \mathrm{~m} / 1.98 \mathrm{~m}$ ) and basal areas per plot (by a factor of $2.7=23.6 \mathrm{~m}^{2} \mathrm{ha}^{-1} / 8.8 \mathrm{~m}^{2} \mathrm{ha}^{-1}$ ) and less pronounced, smaller increases in tree densities (by a factor of $1.2=4,120$ trees $\mathrm{ha}^{-1} / 3,430$ trees ha ${ }^{-1}$ ). Thus, the 2008 forest is primarily a larger, rather than a denser, version of the 1987 forest with a relatively unchanged species composition. The forest also appears to be becoming more uniform as suggested by the reductions in differences among transects in mean density, height and basal area from 1987 to 2008 (Table 2).

There was little indication that the forest becoming larger involved the competitive displacement or inhibition of one species by another. There was little evidence that increases in densities or heights by one of the more abundant species resulted in declining densities or (with the possible exception of $T$. mertensiana) notably slower rates of height growth for the less abundant species. Perhaps an appropriate description of the forest develop- ment over these 21 years is that it approximates a transient equilibrium (or steady state) where ratios of abundances among species and ratios of sizes among species are remaining relatively constant, but the magnitudes of abundances and sizes, are not remaining constant.

There was little indication in 2008 that approaching canopy closure had begun to modify forest composition. Even where canopy cover was nearly complete, there was no indication of declining densities due to selfthinning. There was little evidence of tree mortality from any cause as dead trees were not observed in the sampled plots.

Kroh et al. (2000) described the 1987 forest composition as being typical of the Upper Montane Coniferous forests which commonly occur at elevations from 1800 to $2400 \mathrm{~m}$ in the Northern Sierra Mountains and the Southern Cascade Range (Rundel et al., 1990), and the relatively small changes in species compositions between 1987 and 2008 suggest a continuing similarity to this forest type. These forests typically have basal areas ranging from 50 to $70 \mathrm{~m}^{2} \mathrm{ha}^{-1}$ (Barbour, 1988; Parker, 1991), and the 2008 mean basal area of $23.6 \mathrm{~m}^{2} \mathrm{ha}^{-1}$ illustrates the remaining forest development that may be expected to occur.

The species compositions of the 1987 and 2008 forests are similar to 1) the 1963 forests described by Heath (1967a) and 2) the 1982 data for Fessenden's (1984) SCF. They are similar in that $P$. contorta is clearly more abundant than the other conifer species. The major difference in composition between Heath's (1967a) 1963 transect data and the 1987 and 2008 samplings is that $A$. concolor is more abundant than A. magnifica in Heath's data, whereas $A$. magnifica is the more abundant species in 1987 and 2008. However, this does not necessarily imply a changing forest composition because Heath's 1963 transect was near the lower elevation transects H3 and $\mathrm{H} 4$ where $A$. concolor is relatively more abundant than in the upper transects.

Whatever the factors were that established the initial species composition of the forest; this initial composition has largely persisted with mostly minor changes involving the relative abundances of species. In the various measures of species composition from on the mudflow from 1960 through 2008, the percent composition of $P$. contorta 1) ranged from 43 to $69 \%$, and 2) there was indication of any consistent increasing or decreasing trend. The 1) similar proportional increases in the densities of the conifer species (Table 1) despite 2) a lack of obvious evidence of seed production by trees on the mudflow suggests that the increases in the tree numbers may continue to be determined more by external seed deposition from neighboring tree stands. There are patches of large, seed-producing trees which occur at higher elevations within several hundred meters south of the mudflow forest (Kroh, pers. obs.). These trees are observable in aerial photography beginning in 1940 . 
Thus, it is possible that 1) the combination of external seed input and 2) the absence of pronounced tree mortality may be responsible for the continuing similarity in conifer species composition across years.

\section{Expectations of possible changing abundances for $P$. contorta and the Abies species}

While the canopy cover by 2008 had not produced the anticipated mortality and declining densities indicative of increasing competition, these types of declines have been documented for nearby sites on more fertile lahar deposits. Parker (1993), using plots of $50.6 \times 50.6 \mathrm{~m}$, has demonstrated this expected shift from abiotic to biotic factors by contrasting $P$. contorta populations on the Hat Creek lahar deposits formed during the 19 May 1915 eruption (site 5 in Parker, 1993) with those on a part of the mudflow located near transect $\mathrm{H} 4$ (site 8 in Parker, 1993). These two sites are about 2-km apart with the Hat Creek site being approximately $100-\mathrm{m}$ lower in elevation. The lahar site is predominantly sand whereas the mudflow site is primarily gravel-sized dacite, and the lahar site had at least $25 \%$ more soil nitrogen and phosphorus than the mudflow site (Parker, 1993).

Although both these sites were approximately 70 yearsold, at the time of sampling, there were pronounced differences in their forest structures. The forest on the lahar site had 1) a density of 2,200 live $P$. contorta trees per ha, 2) a basal area of $\left.15.3 \mathrm{~m}^{2} \mathrm{ha}^{-1}, 3\right)$ a visually estimated canopy closure of $91 \%$, and 4 ) $97 \%$ of the $P$. contorta trees were $>1.4-\mathrm{m}$ tall. In addition to the live trees, there were 1,100 standing-dead $P$. contorta trees per ha. In contrast, the mudflow site had 1) a density of 840 live $P$. contorta per ha, 2) a canopy closure of $16 \%$, and 3 ) less than $10 \%$ of the P. contorta were $\geq 1.4-\mathrm{m}$ tall, and 4) there were no standing dead trees. Thus, the lahar site represents a forest with canopy closure where competition for light is likely causing mortality among the smaller, shade intolerant $P$. contorta.

Factors contributing to shade-induced mortality in $P$. contorta may include 1) the lower ability of shaded crowns to draw water to the leaves (Reid et al., 2003), 2) wind related physical damage to trees with shade-induced spindly growth forms (Long and Smith, 1992; Rudnicki et al., 2001), and 3) snow damage to smaller and more spindly trees (Teste and Lieffors, 2011). In shaded conditions, $P$. contorta show a proportionately greater reduction in lateral branch growth relative to vertical growth than other similar species (Chen et al., 1996), and these changes result in a more spindly growth form than that for more shade tolerant species which have proportionately smaller reductions in lateral branch growth relative to vertical growth in shaded conditions (Chen et al., 1996). This greater proportional reduction in lateral branch growth for $P$. contorta results in a more spindly growth form and greater susceptibility to damage from wind and snow and contributes to the tree's common name of lodgepole pine which reflects its use by native American cultures.

Bailey (1961) also noted crowding-induced mortality for $P$. contorta in a $30.3 \times 30.3 \mathrm{~m}$ plot on the Lost Creek lahar. The plot contained 2,630 4.5 to $9 \mathrm{~m}$ tall, $\leq 30$-y old $P$. contorta per ha that were $\leq 30$-years old and $>3,000$ small Abies spp. per ha. From this plot structure, Bailey (1961) postulated an on-going shift in forest composition from $P$. contorta to the numerous, relatively shade-tolerant $A$. concolor and $A$. magnifica in the plot.

Parker (1993) also reports sites where older $P$. contorta stands have $A$. magnifica understories and suggests that $P$. contorta is an initial invader of disturbed locations that will only remain in the forest canopy at sites of chronic disturbance or low fertility. The mudflow is clearly a low fertility site as indicated by the composition of the mudflow materials (Eppler, 1984), the comparison of soil properties with other sites of more robust $P$. contorta (Parker, 1993), and the predominance of short-stature, slow growing trees (Kroh et al., 2000).

Thus, two alternative paths of forest development could be suggested for this mudflow site. Either continuing tree growth will result in a closing canopy with declining abundances of $P$. contorta and increasing abundances of the Abies spp., or the low fertility of the mudflow will result in a continuing forest composed of mostly small $P$. contorta.

\section{Projected near-term forest development on the mudflow}

Although the changes in forest structure between 1987 and 2008 have been relatively minor, they suggest that the mudflow forest is not likely to continue as an open stand of mostly small $P$. contorta but rather may be on the verge of imminent changes that could result in 1) a closing canopy, 2) a self-thinning decline in the abundances of the shade intolerant $P$. contorta, and 3 ) a shift to greater relative abundances of the more shade tolerant $A$. concolor and $A$. magnifica. The potential imminent occurrence of these changes is based on a per plot projection of forest growth using 1) the measured plot basal areas in 1987 and 2008, 2) the basal area proportional growth rates measured for the plot between 1987 and 2008 , 3) equation 1 relating canopy cover to basal area, and 4) the $0.00047^{-1}$ reduction in proportional basal area growth rates for each $1 \%$ increase in canopy cover. The details of the procedures used in making these projections are presented in Appendix I with an example and discussions of assumptions and possible inaccuracies in the projected basal areas and canopy covers.

The distributions of plot basal areas and canopy covers for 2008 and the projected distributions of basal areas and canopy covers among individual plots for 2018 and 2028 are shown in Figures 2 and 3, respectively. Mean basal areas for 2018 and 2028 are projected to be 37.1 and $56.6 \mathrm{~m}^{2} \mathrm{ha}^{-1}$, respectively, and median canopy covers for 2018 and 2028 are projected to be 74 and 


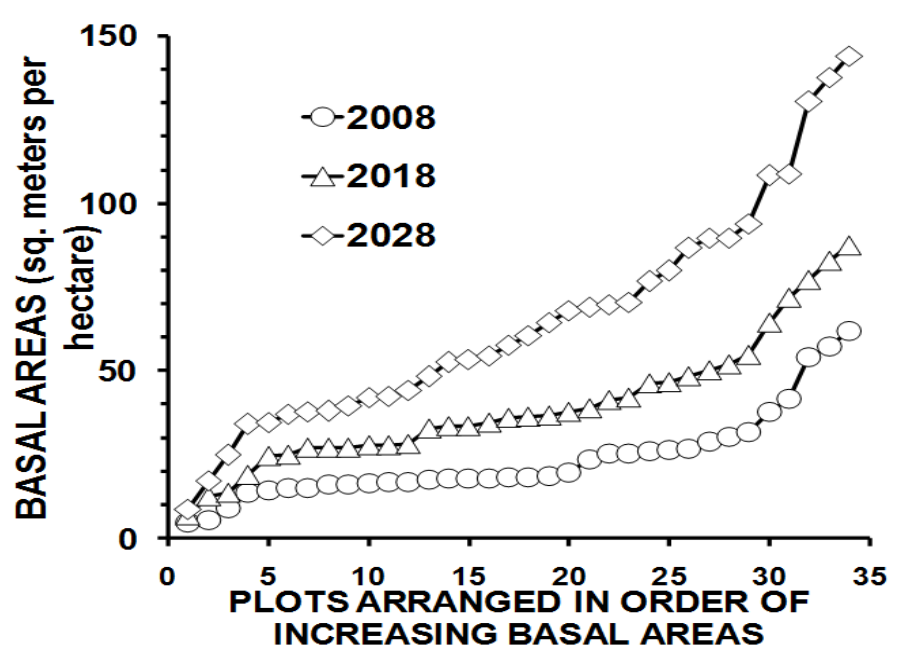

Figure 2. The frequency distribution of basal area $\left(\mathrm{m}^{2} \mathrm{ha}^{-1}\right)$ in 2008 and the projected basal areas expected for 2018 and 2028 as estimated from the plot's 2008 basal area and the proportional rate of increase for the plot for the interval 1987 to 2008. Because of variations among plots for 1) 1987 basal areas per plot and 2) proportional rates of basal area increase between 1987 and 2008, the sequence of plots may vary among years.

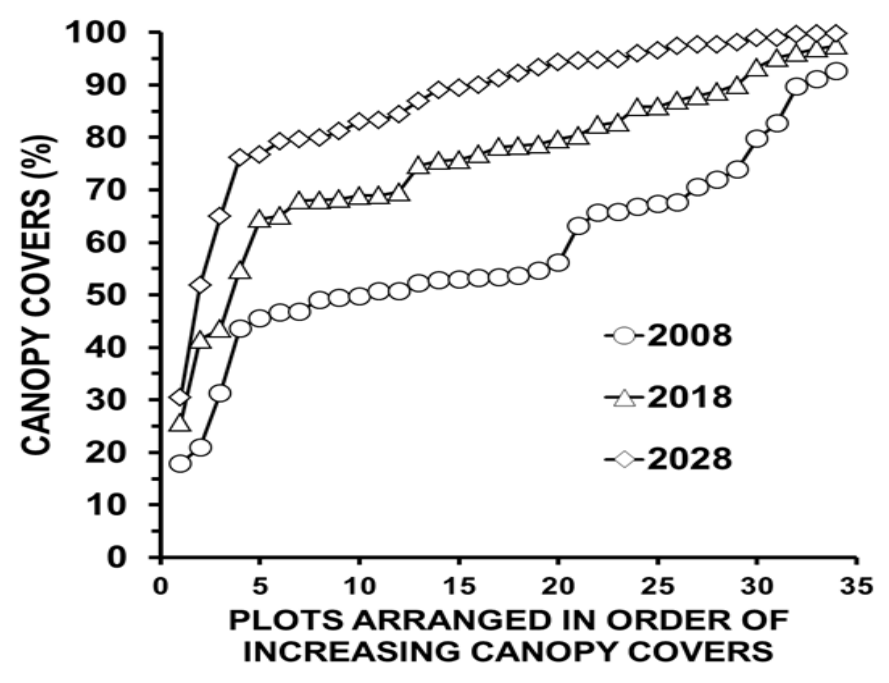

Figure 3. The frequency distribution of the canopy covers (\%) in 2008, 2018, and 2028 for the 34 plots. For consistency among the years, all canopy covers are predicted from either measured (2008) or projected (2018 and 2028) plot basal areas (Figure 2) using Equation 1.

$88 \%$, respectively. These mean basal areas are consistent with the range of 50 to $70 \mathrm{~m}^{2} \mathrm{ha}^{-1}$ reported for mature Upper Montane Coniferous forests by Barbour (1988) and Parker (1991). By 2018 almost 40\% of the canopy covers will be $>80 \%$. By 2028 , more than $70 \%$ of canopy covers will be $>80 \%$ and almost $50 \%$ of the canopy covers will be $>90 \%$.

It may be argued that these projections are merely extensions of trends measured between only the two points in time of 1987 and 2008, but these are the projections that can be made from the available data and the processes that they suggest. Without projections whose accuracy can be quantitatively tested by future measurements, there can be no rigorous test of how well current knowledge forecasts future forest development. Moreover, two aspects of these projections should be emphasized. First, there is not just one projection but one projection for each of the 34 plots based on the unique, specific data for that plot, and relating the accuracy of each plot's prediction to its initial conditions may identify the factors contributing to inaccurate predictions. Second, that these projections are based on a 21 -year interval that encompasses $30 \%$ of the forest's existence $(21 /(2008-1940))$.

These projected increases in canopy covers imply a progressive and rapid (rapid at least for a forest) transition from a mostly open to a mostly closed canopy. Whether the rate of this transition will be 1) faster or 2) slower than these projections remains to be determined from continuing studies of these plots. Moreover, the variations among plots, and to some extent variations among transects, may lead to varying rates of change and varying results of change across the mudflow. When the future development of plots meets these projections and expectations, it may confirm our assumptions and interpretations, but add little to our current knowledge.

However, the questions that may arise if these projecttions are not met, or are met earlier or later than expected, have the potential to increase our understanding of the processes active in the structuring of these forests.

\section{Projected long-term forest development on the mudflow}

If the canopy on the mudflow continues to close as projected in Figure 3 and the expected self-thinning begins, tree densities may then decline, but the declines in density may not be uniformly distributed among the species. This may be especially the case if shading is the primary cause of mortality. Reductions in sub-canopy light intensities may have less impact on the relatively shade-tolerant and relatively long-lived $A$. magnifica, which is the second most abundant species on the mudflow. This shift from a primarily $P$. contorta forest to a primarily A. magnifica forest may be a prolonged process for Parker (1993) reports on LVNP forests of $>100$ yearold forests that have continuing greater abundances of $P$. contorta than $A$. magnifica. However, the tree age distributions in the forests reported by Parker (1993) suggest that the $A$. magnifica were 1 ) later colonizers of the area than the $P$. contorta, and 2) are consequently mostly smaller than the $P$. contorta. In contrast, the transition from $P$. contorta to $A$. magnifica on the mudflow may be more rapid because 1) the age distributions of these two species are similar (Kroh et al., 2000) and 2) their current mean heights are also similar (Table 4). 


\section{The continuing importance of the permanent plots}

The transition from a $P$. contorta to an $A$. magnifica forest may be known or inferred from large-scale plot studies (Parker, 1993), but the scale of these large plots may not reveal 1) which individuals have the greatest potential for surviving and thriving in this transition or 2) to what extent this potential for surviving and thriving is a function of the properties of the individual or of the individual's immediate surroundings. Because the locations, as well as the species, heights and basal areas, have been measured for every individual $\leq 0.11-\mathrm{m}$ tall in 2008, continuing studies of the mudflow plots can move from a plot-based analysis to an individual-based analysis of forest development that can 1) evaluate the success of each individual measured as either its survival and/or growth relative to other individuals and 2) to relate this success to the properties of the individual (species, size) or to the properties of the individual's surroundings (nearness, sizes and species of neighboring individuals). This individual-based analysis can address questions such as, is it merely the largest individuals in the plots that will be successful, or is the process more complex?

Or, are more isolated individuals more likely to persist than merely larger individuals (Fangliang and Duncan, 2000)? There may also be an interaction between size and neighborhood effects as has been demonstrated by Wyckoff and Clark (2000) who found that growth rate for a number of tree species could be predicted from their initial size and the area of the tree's crown that was exposed in the forest canopy.

Moreover, questions also remain concerning the possible inhibitory and facultative interactions among these species. For example, are the effects of $P$. contorta shading only inhibitory or may there be subtle facultative effects for shade tolerant species? Shade may limit growth but may also mediate temperature and moisture regimes with the result that Abies sp., which are more drought sensitive (Minore, 1979), are more likely to become established in the future forest from shaded rather than from exposed plots or sites.

If there are both inhibitory and facilitative effects among these species, their relative importance may be affected by stress levels on the mudflow. Callaway and Walker (1997) reviewed the relative effects of competition and facilitation in plant communities and discuss: 1) model studies by Holmgren et al. (1997) that suggest the alleviation of moisture stress in xeric habitats is more important than light limitation; and 2) the results of Callaway (1998) that suggest that facilitation between Pinus albicaulis and the shade-tolerant (Minore, 1979), but relatively drought intolerant (Minore, 1979) Abies lasiocarpa, is more important than inhibition in high stress environments.

As Herben (1996) discusses, monitoring the fates of individuals of different species and noting their differential survivorship in permanent plots may suggest 1 ) interspecific interactions, 2) more complex interrelationships among species, and 3) causative mechanisms for subsequent experimentation. The fates of individual trees would not identify mechanisms but would suggest which mechanisms and which intraspecific and interspecific interactions are more probable than others and, consequently, are more appropriate for experimental studies. Moreover, the long time frame for forest succession in these plots may also allow hypotheses, projections and models derived from one time frame to be tested in subsequent time frames.

Connell et al. (1987) postulated that the effects of one species upon another in succession could involve both inhibition and facilitation whose net effects could be positive, negative or zero. Nearly zero net observable effects could be indistinguishable from the no effect tolerance model and could make the unravelling of the contrasting effects of one species on another a difficult proposition. A balance of shading effects which 1) reduces photosynthetic rate but 2) moderates moisture stress could result in no effects or in difficult to discern non-zero effects. In this regard, the development of the mudflow forest from 1987 to 2008, which demonstrates an apparently transient equilibrium, raises the issue of whether this represents 1) a general level of interspecific tolerance among most of the species which may not persist as the trees grow larger or 2) complex interactions of inhibition and facilitation.

\section{The investigator's anxiety of very long-term research}

Clearly the delayed forest establishment and the slow tree growth rates on the mudflow substrate have slowed forest development. This has allowed 1) the scientific discipline of ecology to develop the techniques, tools and questions to utilize this resource and 2) the Mt. St. Helens catastrophic eruption to demonstrate the need for a better understanding of forest development in the Pacific Northwest.

However, the slow development is also problematic as the current aging generation of investigators may not witness the accuracy of their projections, the answers to current questions, or the more detailed analyses of the fates of individuals that may lead to testable hypotheses. They may even wonder if there will be those who do.

\section{Conflict of Interests}

The author(s) have not declared any conflict of interests.

\section{ACKNOWLEDGEMENTS}

This study was conducted in Lassen Volcanic National Park with the permission and assistance of Gilbert Blinn, Alan Dennison, Louise Johnson, Sara Koenig and Steven Zachary. Financial and logistical support was provided by 
the U. S. Park Service. Funding for the 2008 sampling was provided by the Texas Christian University Research Foundation. Data analysis resources were provided by the Rocky Mountain Center for Nuclear Computations of the Department of Environmental and Radiological Health Sciences, Colorado State University. We thank Ms. Deborah Flynn and Mr. Cameron Pool for their assistance with the 2008 field work.

\section{REFERENCES}

Acker SS, McKee WA, Harmon ME, Franklin J (1987) Long-term research on forest dynamics in the Pacific Northwest: a network of permanent forest plots, pp. 93-106. In F. Dallmeier \& J. A. Comiskey (eds), Forest biodiversity in North, Central and South America and the Caribbean. The Parthenon Publishing Group Inc. Pearl River, NY. p. 792.

Alejandre-Melena N, Lindig-Cisneros R, Saenz-Romero C (2007). Response of Pinus pseuodstrobus (Lindl.) to fertile growing medium and tephra-layer depth under greenhouse conditions. New Forests34:25-30.

Bailey WH (1961). A repopulation study of the Devastated Area Lassen Volcanic National Park. An unpublished Special Problem Study for Stanford University. Lassen Volcanic National Park Archives, Mineral California. p. 50.

Bailey WH (1963). Revegetation in the 1914-15 Devastated Area of Lassen Volcanic National Park. Ph.D. Thesis. Oregon State University, Corvallis, Oregon. p. 150.

Bakker JP, Olff H, Willems JH, Zobel M (1996). Why do we need permanent plots inthe study of long-term vegetation dynamics? J. Veg. Sci. 7:147-156.

Barbour MG (1988). California upland forests and woodlands, p. 131164. In: Barbour MG and Billings WD (eds.). North American terrestrial vegetation. Cambridge University Press. Cambridge, United Kingdom. p. 724

Brunnel FL, Vales DJ (1990). Comparisons of methods for estimating forest overstory cover: Differences among techniques. Can. J. Forest Res. 20:101-107.

Callaway RM (1998). Competition and facilitation on elevational gradients in subalpine forests of the northern Rocky Mountains, USA. Oikos 82:561-573.

Callaway RM, Walker LR (1997). Competition and facilitation: A synthetic approach to interactions in plant communities. Ecology 78:1958-1965.

Chen HYH, Klinka K, Kayahara GJ (1996). Effects of light on growth, crown architecture and specific leaf area for naturally established Pinus contorta var. latifolia and Pseudotsuga menziessi var. glauca saplings. Can. J. For. Res. 26:1149-1157.

Chytry M, Tichy T, Hennekens S M, Schaminee JHJ (2014). Assessing vegetation change using vegetation-plot databases: a risky business. Appl. Veg. Sci. 17:32-41.

Clarkson DB (1997). Vegetation succession (1967-1989) on five recent montane lava flows, Mauna Loa, Hawaii. N. Z. J. Ecol. 22:1-9.

Connell JH, Noble IR, Slayter RO (1987). On the mechanisms producing successional change. Oikos 50: 136-137.

Conover WJ (1971). Practical nonparametric statistics. John Wiley and Sons, New York. p. 462.

Cook JG, Stutzman TW, Bowes CW, Brenner KA, Irwin LL (1995). Spherical densitometers produce bias estimates of forest canopy cover. Wildlife S. B. 23:711-717.

Csecserits A, Szabo R, Halassy M. Redei T (2007). Testing the validity of successional predictions on an old-field chronosequence in Hungary. Community Ecol. 8:195-207.

Dale VH, Adams WM (2003). Plant establishment 15 years after the debris avalanche at Mount St. Helens, Washington. Sci. Total Environ. 313:101-113.

Dale VH, Cambell DR, Adams WM, Crisafuli CM, Dains VI., Frenzen PM, Holland RF(2005a). Plant succession on the Mount St. Helens debris-avalanche deposit, p. 59-73. In: Dale VH, Swanson FJ, Crisafulli, CM (eds.) Ecological responses to the 1980 eruption of Mount St. Helens. Springer Science + Business Media, Inc. New York. p. 342

Dale VH, Swanson FJ, Crisafulli CM (eds.) (2005b). Ecological responses to the 1980 eruption of Mount St. Helens. Springer Science + Business Media, Inc. New York. p. 342

Davis RR, Foote FS, Anderson JM, Mikhail EM (1981). Surveying theory and practice. Sixth Edition. McGraw Hill Book Co. New York. p. 992.

Dean TJ, Long JN (1992). Influence of leaf area and canopy structure on size-density relationships in even-ages lodgepole pine stands. Forest Ecol. Manag. 49:109-117.

del Moral R (2007). Limits to convergence of vegetation during early primary succession. J. Veg. Sci. 18:479-488.

del Moral R, Grishin SY (1999). Volcanic disturbances and ecosystem recovery, p. 137-160. In: L. R. Walker (ed.). Ecosystems of disturbed ground. Elsevier, Amsterdam. p. 868.

del Moral R, Magnusson B (2014). Surtsey and Mount St. Helens: a comparison of early successional rates. Biogeosciences 11:20992111.

del Moral R, Rozzell LR (2005). Long-term effects of Lupinus lepidus on vegetation dynamics at Mount St. Helens. Plant Ecol. 181:203-215.

del Moral R, Thomason LA, Wenke AC, Lozanoff N, Abata MD (2012). Primary succession trajectories on pumice at Mt. St. Helens Washington. J. Veg. Sci. 23:73-85.

del Moral R., Saura JM, Emenegger JN (2010). Primary succession trajectories on a barren plain, Mount. St.Helens, Washington. J. Veg. Sci. 21:857-867.

Deligne NI, Cashman KV, Roering JJ (2013). After the lava flow: The importance of external soil sources for plant colonization of recent lava flows in the central Oregon Cascades, USA. Geomorphology 202:15-32.

Der G EB (2001). Handbook of statistical analyses using SAS. CRC Press, Bocca Raton, USA. p. 376

Dewar RD (1993). A mechanistic analysis of self-thinning in terms of the carbon balance of trees. Ann. Bot. London 71:147-159.

Dodd $M$ (2011). Where are my quadrats? Positional accuracy in fieldwork. Methods Ecol. Evol. 2:576-584.

Drake DR (1993). Germination requirements of Metrosideros polymorpha, the dominant tree of Hawaiian lava flows and rain forests. Biotropica 25:461-467.

Drake DR, Mueller-Dombois D (1993). Population development of rain forest trees on a chrono sequence of Hawaiian lava flows. Ecology $74: 1012-1019$

El-Rabbany A (2002). Introduction to GPS: the global positioning system. Arctech House, Norwood. p. 196.

Eppler DB (1984). Characteristics of volcanic blasts, mudflows and rockfall avalanches in Lassen Volcanic National Park, California. M. S. Thesis. Arizona State University, Tempe, Arizona. p. 261.

Eppler DB (1987). The May 1915 eruptions of Lassen Peak II: May 22 volcanic blast effects, sedimentology and stratigraphy of deposits, and characteristics of the blast cloud. J. Volcanology Geothermal Res. 31:65-85.

Fangliang HE, Duncan RP (2000). Density-dependent effects on tree survival in an old-growth Douglas fir forest. J. Ecol. 88:676-688.

Fastie CL (1995). Causes and ecosystem consequences of multiple pathways of primary succession at Glacier bay, Alaska. Ecology 76: 1899-1916.

Fessenden JE (1984). Forest biomass and production estimates for the devastated area, Lassen Volcanic National Park, California. M. S. Thesis. Humbolt StateUniversity, Arcata, California. p. 49

Frenzen PM, Franklin JP (1985). Establishment of conifers from seed on tephra depositied by the 1980 eruptions of Mt. Saint Helens, Washington. Am. Midl. Nat. 114:84-97. In: Dale VH, Swanson FJ, Crisafulli, CM (eds.) Ecological responses to the 1980 eruption of Mount St. Helens. Springer Science + Business Media, Inc. New York. p. 342

Frenzen, PM, Hadley KS, Major JJ, Weber MH, Franklin JF, Hardison JH III, Stanton SM (2005). Geomorphic change and vegetation development on the Muddy River mudflow deposit, p. 75-91. In: Dale $\mathrm{VH}$, Swanson FJ, Crisafulli, CM (eds.) Ecological responses to the 
1980 eruption of Mount St. Helens. Springer Science + Business Media, Inc. New York. p. 342.

Griffin JR (1967). Soil moisture and vegetation patterns in northern California forests.Pacific Southwest Forest and Range Experiment Station, Berekey, California. U. S. Forest Service Research paper PSW-46. p. 22.

Halpern CB, Frenzen PM, Means JE, Franklin JF (1990). Plant succession in areas of scorched and blown-down forest after the 1980 eruption of Mount St. Helens, Washington. J. Veg. Sci. 1: 181-194.

Harcombe PA, Bill CJ, Fulton M, Glitzenstein JS, Marks PL, Elisk IS (2002). Stand dynamics over 18 years in a southern mixed-hardwood forest, Texas, USA. J. Ecol. 90:947-957.

Harris SL (1988). Fire mountains of the west: The Cascade and Mono Lake volcanoes. Mountain Press Publishing, Missoula, Montana. p. 379.

Heath JP (1967b). Primary conifer succession, Lassen Volcanic National Park. Ecology 48:270-275.

Heath JP (1971). Changes in thirty-one years in a Sierra Nevada ecotone. Ecology 52:1090-1092.

Heath JP (1967a). Field data to accompany conifer succession, Lassen Volcanic National Park. San Jose State University Special Collections\& Archives. Dr. Martin Luther King Library, San Jose State University, San Jose, California, p. 107.

Herben T (1996). Permanent plots as tools for community ecology. J. Veg. Sci. 7:195-202.

Hickman JC (ed.) (1993). The Jepson manual: Higher plants of California. University of California Press, Berkeley, California. p. 1400.

Holmgren M, Scheffer M, Huston MA (1997). The interplay of facilitation and competition in plant communities. Ecology 78:1966-1975.

Johnson EA, Miyanishi K, Kleb H (1994). The hazards of interpretation of static age structure as shown by stand reconstructions in a Pinus contorta-Picea englemanni. J. Ecol. 82:923-931.

Kangur A, Korjus H, Jogiste K, Kiviste A (2005). A conceptual model of forest stand developmemt based on permanent sample-plot data in Estonia. Scand. J. Forest Res. 20 (Suppl 6):94-101.

Kiver EP (1982). The Cascade volcanoes: Comparison of geological and historical records, p. 3-12. In: Keller SAC (ed.). Mount St. Helens: one year later. Eastern Washington University Press, Cheney, Washington. p. 243.

Kroh GC, White JD, Heath SK, Pinder JE III (2000). Colonization of a volcanic mudflow by an upper montane coniferous forest at Lassen Volcanic National Park, California. Am Midl. Nat. 143:126-140.

Larsen DR, Bliss LC (1998). An analysis of structure of tree seedling populations on a lahar. Landsc. Ecol. 13:307-323.

Lemmon PE (1956). A spherical densitometer for estimating forest overstory density. For. Sci. 2:314-320.

Long, JN, Smith FW (1992). Volume increment in Pinus contorta var. latifolia: the influence of stand development and crown dynamics. For. Ecol. Manage. 53:53-64.

MacDonald GA, Katsura T (1965). Eruptions of Lassen Peak, Cascade Range, California, in 1915: Example of mixed magmas. Geol. Soc. Am. Bull. 76:475-482.

McCune B, Allen TFH (1985). Will similar forests develop on similar sites. Can. J. Bot. 63:367-376.

Milliken GA, Johnson DE (1984). Analysis of messy data. Volume I. Designed experiments. Van Nostran Reinhold Company, New York. p. 473.

Minore D (1979). Comparative autecological characteristics of northwestern tree species - a literature review. U. S. Dept. Agr. For. Serv. Gen. Tech. Rep. PNW-87. p. 72

Morris WF, Wood DM (1989). The role of lupine in succession on Mount St. Helens, facilitation or inhibition. Ecology 70:679-703.

Munoz-Jimenez J, Rangel-Rios K, Garcia-Romero A (2005). Plant colonization of recent lahar deposition on Popocatepetl Volcano, Mexico. Phys. Geogr. 26:192-215.

Nuttle T (1997). Densiometer bias? Are we measuring the forest or the trees. Wildl. Soc. B. 25: 610-611.

Parker AJ (1991). Forest/environmental relationships in Lassen Volcanic National Park, California, U.S.A. J. Biogeogr. 18:543-552.

Parker AJ (1993). Structural variation and dynamics of lodgepole pine forests in Lassen Volcanic National Park, California. Ann. Assoc. Am. Geogr. 83:613-629.

Peet RL, Christiansen NL (1980). Succession: a population process. Vegetatio 43:131-140.

Reid DEB, Silinus U, Lieffers VT (2003). Stem sapwood permeability in relation to crown dominance and site quality in self-thinning fire-origin lodgepole pine stands. Tree Physiol. 23:833-840.

Ross LC, Woodin SJ, Hester A, Thompson DBA, Birks HJB (2010). How important is plot relocation accuracy when interpreting revisitation studies of vegetation change. Plant Ecol. Divers. 3:1-8.

Rudnicki M, Silnus U, Lieffers VJ, Josi G (2001). Measure of simultaneous tree sways and estimation of crown interactions among a group of tree. Trees 15:83-90.

Rundel PW, Parsons DJ, Gordon DT (1990). Montane and subalpine vegetation of the Sierra Nevada and Cascade ranges, p. 559-599. In: Barbour MG and Major J (ed.) Terrestrial vegetation of California. California Native Plant Society. p. 1002.

Spjotvoll E, Stoline MR (1973). An extension of the T-method of multiple comparisons to include the cases with unequal sample sizes. J. Am. Stat. Assoc. 68:975-978.

Stillman AG, Turnage WA (eds.) (1962). Ansel Adams, our national parks. Little Brown and Co., Boston. p.127.

Swartzlow CR (1946). The Devastated Area: A preliminary study in natural reforestation. An unpublished National Park Service Report. Lassen Volcanic National Park Archives, Mineral California. p. 7.

Teste FP, Lieffers VJ (2011). Snow damage in lodgepole pine standings brought into thinning and fertilization regimes. For. Ecol. Manag. 261:2096-2104.

Titus JH, Bishop JG (2014). Propagule limitation and competition with nitrogen fixers during primary succession. J. Veg. Sci. 24: 990-1003.

Turner DP (1985). Successional relationships and a comparison of biological characteristics among six northwestern conifers. B. Torrey Bot. Club 112:421-428.

Upjohn RL (2009). Primary conifer succession in the Devastated Area in Lassen Volcanic National Park, California. M.S. Thesis. Texas Christian University, Fort Worth, Texas. p. 29.

Valverde T, Silvertown J (1997). Canopy closure rate and forest structure. Ecology 78:1555-1562.

Vanderschaaf CL (2010). Estimating individual stand size-density trajectories and a maximum size-density relationship species boundary line slope. For. Sci. 56: 327-335.

Walker LR, Chapin FS III (1987). Interactions among processes controlling successional change. Oikos 50:131-135.

Walker LR, Clarkson BD, Silvester WB, Clarkson BR (2003). Colonization dynamics and facultative impacts of a nitrogen-fixing shrub in primary succession. J. Veg. Sci. 14:277-290.

Walker LR, del Moral R (2003). Primary succession and ecosystem rehabilitation. Cambridge University Press, Cambridge, United Kingdom. p. 442

Walker LR, Wardle DA, Bardgett RD, Clarkson BD (2010). The use of chronosequences in studies of ecological succession and soil development. J. Ecol. 98:725-736.

Weber, MH, Hadley KS, Frenzen PM, Franklin JF (2006). Forest development following mudflow deposition, Mount St. Helens, Washington. Can. J. For. Res. 36: 437-449.

Weiskittel A, Gould P, Temesgen H (2009). Sources of variation in the self-thinning boundary line for three species with varying levels of shade tolerance. For. Sci. 55: 84-93.

Woods KD (2000). Dynamics in late-successional hemlock-hardwood forests over three decades. Ecology 81:110-126.

Wyckoff PH, Clark JS (2005). Tree growth prediction using size and exposed crown area. Can. J. For. Res. 35:13-20.

Yoshida K, Kikuchis S, Nakamura F, Noda M (1997). Dendrochronological analysis of debris flow disturbance on Rishiri Island. Geomorphology 20:135-145.

Zeide B (1995). A relationship between size of trees and their number. Forest Ecol. Manag. 72:265-272.

Zeide B (2001). Natural thinning and environmental change: an ecological process model. Forest Ecol. Manag. 154:165-177. 


\section{APPENDIX I}

\section{Computational procedures for projecting a plot's forest development from 2008 to 2018}

The computations to project a plot's forest development from 2008 to 2028 involve two phases. The first phase involves estimating the proportional rate of basal area increase (hereafter, PRBAI) appropriate for the plot from 2008 to 2009 and computing the increases in basal area and canopy cover for 2009. The second phase involves calculating the yearly increases in basal areas and canopy covers from 2009 to 2028.

\section{Phase I}

The first step in projecting current basal areas and canopy covers across the interval from 2008 to 2028 for each plot was to convert the PRBAI measured across the interval 1987 to 2008, which is an average of the likely declining rates across these years, to a PRBAI appropriate for the year 2008. Declining values of PRBAI can to be expected to have occurred during the interval from 1987 to 2008 due to the negative correlation between canopy cover and basal area increase. Thus, a plot's PRBAI for the 1987 to 2008 interval is a likely overestimate of the PRBAl for the 2008 to 2009 interval.

To estimate a rate for 2008 to 2009, 1) Equation 1 was used to predict the canopy covers for 1987 and 2008 from the measured basal areas for those dates; 2) an average rate of increasing canopy covers (\% per year) for this interval was computed as the predicted cover for 2008 minus that for 1987 divided by 21 years; and 3) the predicted PRBAl for 2008 was then computed as the average PRBAl for the interval minus 10.5 times the average yearly rate of increasing canopy covers times the $0.00047 \mathrm{y}^{-1}$ reduction in PRBAl per percent increase in canopy cover. These adjustments for the 34 plots resulted in an average reduction in the PRBAl from the 1987 to 2008 interval of $13 \%$ with a range from 3 to $17 \%$.

\section{Example of phase I computations}

As an example of the Phase I procedures, the following computations are for a plot whose 1987 basal area was near the median for that year.

First, for the 1987 and 2008 basal areas of 4.42 and $18.1 \mathrm{~m}^{2} \mathrm{ha}^{-1}$, respectively, the projected canopy covers for 1987 and 2008, as estimated by Equation 1, are 17.0 and $53.3 \%$.

Second, the average yearly rate of canopy cover increase for this 21 year period was: $1.729 \% \mathrm{y}^{-1}=(53.3 \%$ $-17.0 \%) / 21 \mathrm{y}$.

Third, the measured PRBAl for the plot in the interval was $0.07042 \mathrm{y}^{-1}$, and the adjusted PRBAl for 2008 becomes: $0.0619 \mathrm{y}^{-1}=0.07042 \mathrm{y}^{-1}-10.5 \mathrm{y}\left(1.729 \% \mathrm{y}^{-1} \mathrm{x}\right.$ $0.00047 \% y^{-1}$ )

There are numerous sources for possible errors in estimating these adjusted PRBAl for 2008; however, the alternative of using the PRBAl for the 1987 to 2008 interval, which is likely an overestimate, could introduce a positive bias which is the basal area and canopy cover growth rates. In the above computations, it would have been preferable to have densitometer measurements of percent cover for each plot in 1987, but these data were not collected.

\section{Phase II}

The projected yearly increases in basal areas and canopy covers were computed for the years 2009 through 2028 by using the plot's measured 2008 basal area and estimated PRBAl for the 2008 to 2009 interval as a base, 2) using that estimated PRBAl to predict a basal area for the following year; 2) using that predicted basal area to estimate canopy cover for that year; 3) computing the increase in canopy cover\% between the two years; 4) using this increase in canopy cover to estimate a reduction in the PRBAI as $0.00047 \mathrm{y}^{-1}$ times the increase in canopy cover between years; and 5) repeating these steps successively for each year from 2008 through 2028 for each of the 34 plots.

\section{Example phase II computations}

As an example of the Phase II procedures, the following computations are for the plot used in Phase I.

First, using the $0.0619 \mathrm{y}^{-1}$ PRBAl for the interval 2008 to 2009 , the projected basal area for 2009 becomes: 18.1 $\mathrm{m}^{2} \mathrm{ha}^{-1}=17.0 \mathrm{~m}^{2} \mathrm{ha}^{-1} \times \mathrm{e}^{(0.0619 \mathrm{y}-1 \times 1 \mathrm{y})}$

Second, the projected canopy cover for 2009 from equation 1 is $55.5 \%$.

Third, the increase in canopy cover from 2008 to 2009 becomes: $2 \%=55.5-53.3 \%$

Fourth, the projected PRBAI for 2010 becomes: 0.0608 $y^{-1}=0.0619 y^{-1}-\left(2 \% \times 0.00047 y^{-1} \%^{-1}\right)$

Continuing these yearly computations through 2018 and 2028 result in projected basal areas of 31.2 and $52.2 \mathrm{~m}^{2}$ $\mathrm{ha}^{-1}$, respectively, with canopy covers of 74 and $89 \%$ in these same years. The pattern of declining exponential rates of canopy cover increase is consistent with the analyses of canopy closure using Markov-chain models by Valverde and Silvertown (1997).

These computations assume 1) that the proportional basal area growth rates from 1987 to 2008 are applicable to the following 20 years and 2) that Equation 1 is applicable to estimating plot canopy covers in the years preceding 2008 and will continue to be applicable in 
estimating covers in the succeeding 20 years. The current basal area proportional growth rates have been computed over a 21-y span. The length of this span suggests that barring any major disturbance, severe climate change, or pronounced slowing in basal area growth rates due to crowding, these rates should be applicable the next 10 to 20 years following the 2008 sampling. The Equation 1 relationship between basal area and canopy cover may be complicated by continuing increases in mean tree heights which could contribute to greater canopy closure as measured by spherical densitometers. If this occurs, this complication would mean that projected canopy covers using Equation 1 may likely be underestimates of actual covers. 